\title{
The Risk Factors for Immune System Impairment and the Need for Lifestyle Changes
}

\author{
Gunjan Y. Trivedi ${ }^{1 \odot}$ Banshi Saboo $^{2}$ \\ ${ }^{1}$ Shri Jagdishprasad Jhabarmal Tibrewala University, Churela, \\ Rajasthan, India \\ 2 Society for Energy \& Emotions, Wellness Space, Ahmedabad, \\ Gujarat, India
}

\begin{abstract}
Address for correspondence Gunjan Y. Trivedi, Co-Founder, Society for Energy \& Emotions, Wellness Space, 119C Swastik Society, Navrangpura, Ahmedabad, Gujarat, 380009, India (e-mail: gunjan@wellness-space.net).
\end{abstract}

J Soc Health Diab:2020;8:25-28
Abstract
Keywords
- chronic disease
- immune system risk factors
- infectious disease
- lifestyle choices

\begin{abstract}
Healthy immune system helps in enhancing the quality of life and reduces the risk of infectious disease. Chronic disease increases the risk of immune system impairment. The article reviews the evidence on risk factors causing immune system imbalance and articulates the complex nature of the relationships between immune system risk factors, chronic disease, and infectious disease to highlight the importance of lifestyle choices. Finally, some evidence is presented on mind-body interventions and lifestyle choices for enhancing the immune system function.
\end{abstract}

\section{Introduction}

Recent developments of COVID-19 pandemic highlight the importance of the immune system in quality of well-being and preventive health management. The scientific evidence indicates that individuals with immune system impairment or those on medications that suppress the immune system are considered to be at much greater risk of any respiratory infections. ${ }^{1}$ It is also well-known that the number of individuals exposed to infection is much higher than those presenting with the disease, confirming that most individuals can destroy the microorganisms and prevent the infection or slow down the progression. Unfortunately, impaired immune system increases the susceptibility to any infections, and a presence of any chronic disease (e.g., Type 2 diabetes) further increases the risk of impairment in the immune system. ${ }^{2,3}$ Finally, the immunological studies over several years have confirmed that in many infectious diseases, the main pathological aspects are not related to the direct action of an aggressor agent, but an abnormal immune response. ${ }^{4}$ Together, the evidence points to understanding the risk factors for immune system impairment. The article reviews these risk factors, the linkage with chronic and infectious disease, the extent of choice the individual or the society has to influence the risk factors, and the implications for the individual and the clinician.

\section{Key Immune System Risk Factors and Linkage with Disease and Quality of Life}

- Table 1 (risk factors for immune system impairment) highlights the evidence of key risk factors impacting the immune system often through the pathway that includes increased (chronic) inflammation. Many of these factors are also the risk factors for chronic disease and as discussed earlier, the impaired immune system increases the risk of infectious disease., ${ }^{5,6}$

The evidence above confirms that the risk factors for chronic disease also have an adverse impact on the immune system, resulting in increased risk for the infectious disease.

\section{Lack of Quantitative Evidence between Specific Risk Factors and the Immune System Impairment}

Scientific studies have not yet been able to establish a quantitative relationship between altered immune response and frequency or severity of disease in humans due to genetic dissimilarity and heterogeneous form of environmental exposure and finally lifestyle choices. ${ }^{25}$ This is further confounded by the impact of life stage, gender, use of certain medications, drug/alcohol usage, tobacco history, stress, lifestyle, occupation, and nutritional status. ${ }^{26}$ This indicates that despite the evidence of the risk factors impairing the immune system, it
DOI https://doi.org/ $10.1055 / \mathrm{s}-0040-1715778$ ISSN 2321-0656. (c) 2020. Novo Nordisk Education Foundation.

This is an open access article published by Thieme under the terms of the Creative Commons Attribution-NonDerivative-NonCommercial-License, permitting copying and reproduction so long as the original work is given appropriate credit. Contents may not be used for commercial purposes, or adapted, remixed, transformed or built upon. (https://creativecommons.org/licenses/by-nc-nd/4.0/).

Thieme Medical and Scientific Publishers Pvt. Ltd. A-12, 2nd Floor, Sector 2, Noida-201301 UP, India 
Table 1 Risk factors for immune system impairment

\begin{tabular}{|c|c|c|}
\hline Lifestyle choice & Impact on the immune system & Discussions and implications \\
\hline $\begin{array}{l}\text { Poor diet } \\
\text { (includes macro- and micronutrient } \\
\text { imbalance) impacts both innate and } \\
\text { adaptive immune systems. }{ }^{7}\end{array}$ & $\begin{array}{l}\text { Undernutrition due to } \\
\text { insufficientmacronutrients and/or } \\
\text { deficiencies in specific micronutrients } \\
\text { impairs the immune system, suppressing } \\
\text { immune functions that are fundamental to } \\
\text { host protection. }{ }^{8} \\
\text { Sufficient scientific evidence confirms that } \\
\text { nutrient intake above recommended levels } \\
\text { may positively impact the immune function } \\
\text { and modulate chronic inflammatory and } \\
\text { autoimmune condition while decreasing } \\
\text { infection risk.7 }\end{array}$ & $\begin{array}{l}\text { Improving the quality of diet must be } \\
\text { incorporated with the help of clinician. } \\
\text { There is a role of the individual, family, and } \\
\text { the society and the need for collabora- } \\
\text { tion between dietician, clinicians and the } \\
\text { individual. }\end{array}$ \\
\hline $\begin{array}{l}\text { Physical inactivity } \\
\text { Lack of physical activity impairs the } \\
\text { immune system and extreme physical } \\
\text { activity may temporarily affect the } \\
\text { immune system. }\end{array}$ & $\begin{array}{l}\text { The evidence confirms physical activity } \\
\text { (moderate-to-vigorous intensity, less than } \\
60 \text { minutes) helps in enhancing the immune } \\
\text { system. } \\
\text { Regular exercise training has an overall } \\
\text { anti-inflammatory influence mediated } \\
\text { through multiple pathways. }^{9} \\
\text { The evidence also highlights the negative } \\
\text { impact on the immune system of severe }^{\text {exercise. }}{ }^{10}\end{array}$ & $\begin{array}{l}\text { Watchout: Extreme workload (exercise) } \\
\text { could adversely impact the immune system. } \\
\text { It is best to pursue WHO guidelines on } \\
\text { physical activity. }{ }^{11}\end{array}$ \\
\hline $\begin{array}{l}\text { Obesity } \\
\text { Obesity is a disease as well as the risk } \\
\text { factor for chronic disease and immune } \\
\text { system impairment. }\end{array}$ & $\begin{array}{l}\text { Clinical and epidemiological data support } \\
\text { the evidence that the incidence and severity } \\
\text { of specific types of infectious illnesses are } \\
\text { higher in obese persons as compared with }^{\text {lean individuals. }}{ }^{12} \\
\text { Adipose tissuesand chronic inflammation } \\
\text { are linked to suppression of the immune } \\
\text { system along with the presence of metabolic } \\
\text { syndrome parameters. }{ }^{13}\end{array}$ & $\begin{array}{l}\text { Obesity and metabolic syndrome need both } \\
\text { lifestyle and clinical interventions. }\end{array}$ \\
\hline $\begin{array}{l}\text { Chronic Stress } \\
\text { "Stress-related disease emerges, } \\
\text { predominantly, out of the fact that } \\
\text { we so often activate a physiological } \\
\text { system that has evolved for responding } \\
\text { to acute physical emergencies, but we } \\
\text { turn it on for months on end, worrying } \\
\text { about mortgages, relationships, and } \\
\text { promotions"14. }\end{array}$ & $\begin{array}{l}\text { There is direct linkage between chronic } \\
\text { stress and a broad spectrum of human } \\
\text { diseases. }{ }^{15} \\
\text { Stressors can increase the risk of developing } \\
\text { infectious disease, and they can also prolong } \\
\text { infectious illness episodes. }{ }^{16} \\
\text { Chronic stress also increases the risk of } \\
\text { immune system impairment through path- } \\
\text { ways that include chronic inflammation. }{ }^{17} \\
\text { Psychological stress can deregulate the } \\
\text { human immune system. Stress can impact } \\
\text { immunity differentially across individuals } \\
\text { and contexts. }{ }^{17}\end{array}$ & $\begin{array}{l}\text { Lifestyle choices play a very important part } \\
\text { for addressing chronic stress. Being able to } \\
\text { identify the presence of chronic stress is the } \\
\text { first step. Thus, it is important not only for } \\
\text { the clinician but also the family member to } \\
\text { identify and individual who is stressed and } \\
\text { seek appropriate help. }\end{array}$ \\
\hline $\begin{array}{l}\text { Sleep disruption } \\
\text { Sleep disruption has implications affecting } \\
\text { the nervous system, endocrine system, } \\
\text { energy balance, inflammation (and } \\
\text { therefore immune system) and cognitive } \\
\text { functions. }\end{array}$ & $\begin{array}{l}\text { Prolonged sleep disruption and increased } \\
\text { stress due to it results in increased } \\
\text { production of pro-inflammatory cytokines } \\
\text { causing low-grade chronic inflammation that } \\
\text { results in immune system impairment. }{ }^{18} \\
\text { The relationship between sleep and immune } \\
\text { function is bidirectional and increased sleep } \\
\text { disruption increases the risk of infectious } \\
\text { disease. }^{19}\end{array}$ & $\begin{array}{l}\text { Clinicians must screen for sleep disruption } \\
\text { through simple self-reported surveys, } \\
\text { especially for individuals at high risk of } \\
\text { immunosuppression or chronic disease. }\end{array}$ \\
\hline Alcohol consumption & $\begin{array}{l}\text { Alcohol consumption decreases immune } \\
\text { system function, in general though there is } \\
\text { some evidence that moderate amount of } \\
\text { alcohol can enhance the immune system } \\
\text { (due to anti-inflammatory impact). }{ }^{20}\end{array}$ & $\begin{array}{l}\text { Given the serious health risks associated } \\
\text { with exceeding two drinks per day, } \\
\text { increased alcohol consumption cannot be } \\
\text { recommended. }^{21}\end{array}$ \\
\hline $\begin{array}{l}\text { Tobacco consumption } \\
\text { (Includes smoking and chewing tobacco) }\end{array}$ & $\begin{array}{l}\text { Ample evidence has shown that both } \\
\text { innate immunity and adaptive immunity } \\
\text { are susceptible to cigarette smoke, which } \\
\text { interrupts immunological homeosta- } \\
\text { sis, causes various diseases, and exerts } \\
\text { paradoxical effects on immune and tissue } \\
\text { cells. }{ }^{22,23} \text { Chewing tobacco is also linked to } \\
\text { immune system impairment. }^{24}\end{array}$ & $\begin{array}{l}\text { Despite the anti-inflammatory benefits } \\
\text { of nicotine, smoking in general has an } \\
\text { overall negative impact and hence not } \\
\text { recommended. Any form of tobacco is likely } \\
\text { to impair the immune system. }\end{array}$ \\
\hline
\end{tabular}


is not possible to clearly link one or many risk factors with likely occurrence of immune impairment or disease. In other words, the intervention through lifestyle choice must address all the risk factors.

\section{The Importance of Lifestyle Choices and Self-Regulation}

The above evidence makes a strong case for lifestyle choices and self-regulation. When the individual meets one or more risk factors, there is an increased probability of immune system impairment that may increase the risk for infectious and chronic disease. Many of these risk factors are controllable and could be managed if the individual or the society as a whole understands and incorporates changes to reduce the risks. Evidence indicates that adults who have poor self-regulation are more likely to have health challenges (e.g., self-efficacy, coping, adherence, and negative effects on health parameters) that affects the quality of life due to chronic disease. ${ }^{27}$ From health professionals' perspective, it is important to find ways to enhance the self-regulatory skills to slow down the disease progression and also enhance the quality of life..$^{28}$

\section{Evidence on Mind-Body Interventions}

Mind-body medicine focuses on the relationships between the brain, mind, body, behavior, and their effect on health and disease. According to the National Center for Complementary and Alternative Medicine, it encompasses a large group of therapies such as hypnosis, meditation, yoga, biofeedback, tai chi, and visual imagery. Relaxation training had the strongest scientific evidence of a mind-body medicine affecting immune outcomes. ${ }^{29}$ Regular practice of yoga including slow breathing or pranayama, tai chi, and meditation also have a positive impact via reduction of inflammation (C-reactive protein), thereby enhancing the immune function. ${ }^{30,31} \mathrm{To}$ summarize, practices that reduce stress, enhance relaxation, and help in enhancing sleep can improve the immune system, provided they are incorporated into daily routine or lifestyle.

\section{Conclusion}

Many positive lifestyle choices such as quality diet, regular physical activity, maintaining ideal body-weight, good stress management practices, quality sleep and no alcohol or tobacco consumption can help in reducing the chronic inflammation and thereby enhancing the immune system function. This is more relevant for individuals with chronic disease since the presence of chronic disease results in impairment of the immune function.

The evidence also confirms that there is no quantitative relationship to identify the linkage between a risk factor and the impairment of the immune system. Hence, making a healthy lifestyle choice is not a one-time intervention on one risk factor but an overall lifestyle change across multiple risk factors on a going basis.

Making the correct lifestyle intervention, when governed by self-regulation, helps in enhancing the immune system that can help in protection against infectious disease and help in improving Quality of Life for individuals with chronic disease.

\section{Conflict of Interest}

None declared.

\section{References}

1 Australasian Society of Clinical Immunology and Allergy Website. Available at: https://www.allergy.org.au/patients/ immunodeficiencies/covid-19-and-immunodeficiency. Accessed March 15, 2020

2 Janeway CA Jr. How the immune system protects the host from infection. Microbes Infect 2001;3(13):1167-1171

3 Geerlings SE, Hoepelman AI. Immune dysfunction in patients with diabetes mellitus (DM) FEMS Immunol Med Microbiol 1999;26(3-4):259-265

4 Machado PRL, Araújo MIAS, Carvalho L, Carvalho EM. Immune response mechanisms to infections. An Bras Dermatol 2004;79(6):647-662

5 Trivedi Gunjan Y, Hemalatha R, Ramani KV, Chronic Diseases and Mind Body Management: An Introduction (Technical Note), Reference No: CMHS0044TEC. Indian Institute of Management; 2018

6 International Diabetes Federation. Available at: https://www. idf.org/. Accessed March 15, 2020

7 Wu D, Lewis ED, Pae M, Meydani SN. Nutritional modulation of immune function: analysis of evidence, mechanisms, and clinical relevance. Front Immunol 2019;9:3160

8 Marcos A, Nova E, Montero A. Changes in the immune system are conditioned by nutrition. Eur J Clin Nutr 2003;57(1, Suppl 1): S66-S69

9 Nieman DC, Wentz LM. The compelling link between physical activity and the body's defense system. J Sport Health Sci 2019;8(3):201-217

10 Pedersen BK. Influence of physical activity on the cellular immune system: mechanisms of action. Int J Sports Med 1991;12(Suppl 1):S23-S29

11 Physical Activity \& Aduluts. World Health Organization website. Available at: https://www.who.int/dietphysicalactivity/ factsheet_adults/en/. Accessed March 17, 2020

12 Martí A, Marcos A, Martínez JA. Obesity and immune function relationships. Obes Rev 2001;2(2):131-140

13 Patel PS, Buras ED, Balasubramanyam A. The role of the immune system in obesity and insulin resistance. J Obes 2013;2013:616193

14 Segerstrom SC, Miller GE. Psychological stress and the human immune system: a meta-analytic study of 30 years of inquiry. Psychol Bull 2004;130(4):601-630

15 Boscarino JA. Diseases among men 20 years after exposure to severe stress: implications for clinical research and medical care. Psychosom Med 1997;59(6):605-614

16 Glaser R, Kiecolt-Glaser JK. Stress-induced immune dysfunction: implications for health. Nat Rev Immunol 2005;5(3): 243-251

17 Morey JN, Boggero IA, Scott AB, Segerstrom SC. Current directions in stress and human immune function. Curr Opin Psychol 2015;5:13-17

18 Besedovsky L, Lange T, Born J. Sleep and immune function. Pflugers Arch 2012;463(1):121-137

19 Ibarra-Coronado EG, Pantaleón-Martínez AM, VelazquézMoctezuma J, et al. The bidirectional relationship between sleep and immunity against infections. J Immunol Res 2015; 2015:678164

20 Sarkar D, Jung MK, Wang HJ. Alcohol and the immune system. Alcohol Res 2015;37(2):153-155 
21 Romeo J, Wärnberg J, Nova E, Díaz LE, Gómez-Martinez S, Marcos A. Moderate alcohol consumption and the immune system: a review. Br J Nutr 2007;98(Suppl 1):S111-S115

22 Qiu F, Liang CL, Liu H, et al. Impacts of cigarette smoking on immune responsiveness: up and down or upside down? Oncotarget 2017;8(1):268-284

23 Sopori M. Effects of cigarette smoke on the immune system. Nat Rev Immunol 2002;2(5):372-377

24 Willis D, Popovech M, Gany F, Zelikoff J. Toxicology of smokeless tobacco: implications for immune, reproductive, and cardiovascular systems. J Toxicol Environ Health B Crit Rev 2012;15(5):317-331

25 House RV, Fundamentals of clinical immunotoxicology. In:Immunotoxicity Testing. Humana Press; 2010 ; 363-384

26 DeWitt JC, Germolec DR, Luebke RW, Johnson VJ. Associating changes in the immune system with clinical diseases for interpretation in risk assessment. Curr Protoc Toxicol 2016;67(1):18.1.1-18.1.22

27 Lansing AH, Berg CA. Adolescent self-regulation as a foundation for chronic illness self-management. J Pediatr Psychol 2014;39(10):1091-1096

28 Weidner G, Sieverding M, Chesney MA. The role of self-regulation in health and illness. Psychol Health Med 2016;21(2):135-137

29 Wahbeh H, Haywood A, Kaufman K, Zwickey H. Mind-body medicine and immune system outcomes: a systematic review. Open Complement Med J 2009;1:25-34

30 Morgan N, Irwin MR, Chung M, Wang C. The effects of mindbody therapies on the immune system: meta-analysis. PLoS One 2014;9(7):e100903

31 Sengupta P. Health impacts of yoga and pranayama: a state-ofthe-art review. Int J Prev Med 2012;3(7):444-458 